\title{
Sanal Gerçeklik Teknolojilerinin Ortaokulda Kullanım ve Tercih Durumlarının Belirlenmesi* $^{*}$
}

\section{Gürkan YILDIRIM**, Serkan YILDIRIM***}

Öz: Sanal gerçeklik (SG) teknolojileri bilgisayar tarafından üretilen üç boyutlu gerçekçi bir simülasyon deneyimi olarak tanımlanabilir. Günlük hayatın içindeki yerini almaya başlamış bu teknolojilerin öğretim süreçlerindeki etkilerinin incelenmesi ve muhtemel kullanım tercihlerinin belirlenmesi önemli görülmektedir. Bu bağlamda mevcut araştırma kapsamında gelecekte bu teknolojiyi kullanacak olan ortaokul öğrencilerinin SG teknolojilerinin kullanım süreçlerine ve kullanım tercihlerine yönelik görüşlerinin belirlenmesi amaçlanmıştır. Bu amaç doğrultusunda nitel araştırma yöntemlerinden biri olan durum çalışması tercih edilmiştir. Çalışma grubunu amaca uygun olarak seçilen 10 erkek 19 kız olmak üzere toplam 29 ortaokul öğrencisi oluşturmaktadır. Verilerin toplanmasında araştırmacılar tarafından geliştirilen yarı yapılandırılmış görüşme formu kullanılmıştır. Veriler içerik analizi yöntemiyle incelenmiş ve görüşler belirlenen kod ve kategoriler altında toplanmıştır. Araştırma kapsamında SG teknolojilerinin ortaokul düzeyinde yüksek düzeyde tanındığı ancak kullanım açısından yeterince tecrübe edilmediği görülmüştür. Bunun yanı sıra SG teknolojilerinin özellikle eğlence ve eğitim amaçlı kullanılmak istendiği belirlenmiştir. Ayrıca eğitsel amaçlı SG kullanımında özellikle bilişim teknolojileri, fen bilimleri ve sosyal bilgiler alanlarında etkili olabileceğinin düşünüldüğü görülmüştür. Bu derslerin seçilmesinde özellikle somut öğrenme yaşantıları geliştirilmesi ihtiyacının önemli bir etkisinin olduğu söylenebilir. Buna ek olarak SG teknolojilerinin etkili ve eğlenceli öğrenme yaşantıları geliştirmede önemli olabileceği söylenebilir. eğilimler

Anahtar Kelimeler: Sanal gerçeklik, SG teknolojileri, öğretim teknolojileri, yeni

* Bu çalışma 13. Uluslararası Bilgisayar ve Öğretim Teknolojileri Sempozyumu'nda (2-4 Mayıs 2019) sözlü bildiri olarak sunulmuştur.

${ }^{* *}$ Dr. Öğr. Üyesi Bayburt Üniversitesi, Eğitim Fakültesi, Bilgisayar ve Öğretim Teknolojileri Eğitimi Bölümü, gyildirimbote@gmail.com, https://orcid.org/0000-0003-1314-0275

${ }_{* * *}$ Dr. Öğr. Üyesi Atatürk Üniversitesi, Kazım Karabekir Eğitim Fakültesi, Bilgisayar ve Öğretim Teknolojileri Eğitimi Bölümü, serkanyil@gmail.com, https://orcid.org/0000-0002-8277-5963

$\begin{array}{lll}\text { Gönderim:16.10.2019 Kabul:26.12.92019 } & \text { Yayın: 29.02.2020 }\end{array}$ 


\section{Determining The Use and Preference of Virtual Reality Technologies in Secondary School}

Abstract: Virtual reality (VR) technologies can be defined as a three-dimensional realistic simulation experience produced by the computer. It is important to examine these technologies, as they starts to take their place in daily life. VR technologies should be studied in an instructional manner in order to determine their possible usage preferences. In this context, it was aimed to determine the views of secondary school students on the use of VR technologies and their preferences of usage. The case study method was utilized. A total of 29 secondary school students (10 boys and 19 girls) were selected for the research. The semi-structured interview form was used to collect the data. The data were analyzed by content analysis method. Findings revealed that, VR technologies were recognized at high level in secondary school but they were not experienced much in terms of usage. It is determined that VR technologies are used especially for entertainment and educational purposes. VR is used for educational purposes especially in information technologies, science and social sciences. It can be said that tangible learning experiences has a significant impact in the selection of these courses. Also VR technologies might help to develop effective and enjoyable learning experiences.

Keywords: Virtual reality, VR technologies, instructional technologies, new trends

\section{Giriş}

Gelişen teknolojilerin eğitim alanında nasıl kullanılabileceği, etkilerinin neler olabileceği, kullanıcılarının kabul durumu gibi konular araştırmacılar tarafından merak edilmekte (Groves ve Zemel, 2000) ve mevcut teknolojilerin öğretimsel etkileri günümüzde sürekli incelenmektedir. Son zamanlarda özellikle eğlence amaçlı olarak geliştirilen ve kullanıcılarında farklı ortamlarda bulunma hissi oluşturan Sanal Gerçeklik (Virtual RealitySG) yaygın olarak kullanılmaya başlamıştır. SG teknolojilerinin yaygın kullanımı ve kullanıcılardan genel olarak kabul görme durumu öğretim faaliyetlerinde de kullanılma anlayışını da ortaya çıkarmaktadır.

SG, alanyazında kullanım durumları, teknik özellikleri gibi birçok farklı çerçeveden bakılarak tanımlanmaktadır. Bu bağlamda Mann, Furness, Yuan, Iorio ve Wang (2018) SG'yi, bilgisayar tarafından üretilen gerçekçi bir simülasyon deneyimi olarak tanımlamaktadır. Benzer şekilde Kayabaşı (2005) ise SG teknolojilerini; elektronik ortamlarda üretilen 3B resim veya animasyonların çeşitli teknolojik araçlarla insan zihninde gerçek bir algı oluşturmak ve 
kullanıcılarının bu ortamlarla etkileşimde bulunmasını sağlayan araçlar olarak tanımlamakta hatta SG kavramını "gerçeğin yeniden inşa edilmesi” olduğunu vurgulamaktadır. Genel olarak SG; çeşitli araçlar aracılığıyla (bilgisayar, mobil cihazlar, veritabanı, internet vb.) bireylerin sanal olarak oluşturulan bir ortamın içinde gerçek yaşam deneyimleri yaşayabildikleri, kendilerini geliştirilen ortamın içinde hissettikleri ve bu ortamlarla etkileşim kurabildikleri 3 boyutlu uygulamalar olarak tanımlanmaktadır (Carrozzino ve Bergamasco, 2010; Çavas, Çavas ve Can, 2004; Rheingold, 1991). Bu tanımlarda ortaya çıkan en önemli nokta SG teknolojilerinin elektronik ortamlarda ve üç boyutlu (3B) olarak üretilen nesnelerin kullanıcılarına gerçek bir ortamda bulunma hissi yaşatmak olduğu söylenebilir.

SG teknolojileri günümüzde birçok alanda etkili bir şekilde kullanılmaktadır. Özellikle sağlık, askeri, eğitim ve eğlence gibi başat sektörlerde (Civelek-Oruç, Yıldırım, İmamoğlu, Demirel ve Bilgin, 2017; Kayabaş1, 2005) olmak üzere SG teknolojileri kendilerine turizm, üretim, e-ticaret ve yapılaşma gibi sektörlerde geniş uygulama alanları bulmaktadır (Başaran, 2010). Buna ek olarak Çavas ve diğ. (2004) ise eğitim alanında SG uygulamalarının özel eğitim, mimarlık, tarih - coğrafya, fen - matematik, tıp eğitimi ve askeri - havayolu endüstrisinde de etkin bir şekilde kullanılabileceğini belirtmektedir.

Eğitim ortamlarında da öğrenmeyi gerçekleştirme, pekiştirme veya kullanıc1 anlayışlarını ortaya çıkarmayı hedefleyen uygulamaları içeren SG teknolojilerinin öğrenme ortamlarında da etkisini belirlemeye yönelik alanyazında birçok araştırmanın yapıldığı görülmektedir (Tilhou, Taylor ve Crompton, 2020; Vesisenaho ve diğ., 2019). Bu araştırmalarda genel olarak SG teknolojilerinin öğrenme faaliyetleri çerçevesinde üstün olduğu ve sınırlı kaldığı yönler belirtilmiştir. Alanyazında SG teknolojilerinin sunmuş olduğu üstün yönler ve sınırlılıklar Şekil 1'de özetlenmiştir. 
Üstün Yönler (Başaran, 2010; Chavan, 2016; Çavaş, Çavaş ve Can, 2004;

Nooriafshar, Williams ve Maraseni, 2004; Steuer, 1992; Youngblut, 1998)

- Gerçek yaşam deneyimleri oluşturabilir.

-Sunulan eğitimin daha rahat ve kolay olmasını sağlayabilir.

- Kullanicilar yapay bir ortamda deney yapabilir.

- Kullanıcılar kendilerini ortamın bir parçası gibi gördüğünden derse karşı ilgi ve motivasyonu artırabilir.

-Sınıf ortamında gösterilmesi imkansız, tehlikeli ve maliyetli olan uygulamaların gösterilmesinde etkili olabilir.

- Öğretim ortamlarında öğrenmeyi destekleyici aktivitelerin geliştirilmesini sağlayabilir.

-Yüksek düzeyde etkileşim sağlayabilir.

-Engelli bireylerin gerçek yaşam deneyimi yaşamalarını, gözlem yapabilmelerini ve ögrenmelerini kolaylaştırabilir.

\section{Sinırl111klar (Chavan, 2016; Nedas, Challacombe ve Dasgupta, 2004)}

-Yazılımların geliştirilmesi zordur.

-Uygulamaların görüntü kalitesi nedeniyle istenilen gerçeklik etkisi oluşturulamayabilir.

- Gerçek yaşam yerine sanal ortamlar üzerinden deneyim oluşturur.

-SG ortamlarındaki eğitim ile gerçek ortamdaki eğitim aynı sonucu ve başarı durumunu vermeyebilir.

Şekil 1. SG teknolojilerinin öğretimsel üstün ve sınırlı yönleri

SG teknolojilerinin alanyazında belirtilen birçok üstün yönü bulunmaktadır. Bu durum SG teknolojilerinin öğrenme yaşantılarını destekleme potansiyelini ortaya koymaktadır. Ayrıca SG teknolojileri genellikle tıp ve turizm gibi alanlarda yoğunlaştığı görülmektedir. Ancak bu teknolojilerin öğrenme ortamlarında da önemli bir potansiyele sahip olduğu ve öğrenme çıktıları üzerinde birçok olumlu etkiye sebep olduğu alanyazında sıklıkla belirtilmektedir (Alhalabi, 2016; Vesisenaho ve diğ., 2019; Webster, 2016). Geniş bir kullanıcı potansiyeli olan bu teknolojinin kullanıcılar üzerindeki etkilerinin ve kullanıcı görüşlerinin ortaya çıkarılması SG teknolojilerinin öğrenme ortamında kullanım seviyelerini, geliştirilecek öğretim materyallerini ve aktivitelerine yol gösterici olacağı düşünülmektedir. Çünkü alanyazında bazı araştırmalarda SG uygulamalarının öğretimsel etkisinin aslında belirtilenin aksine oldukça sınırlı olduğu vurgulanmaktadır (Stepan ve diğ., 2017). Bu açıdan bakıldığında çalışma kapsamında mevcut teknolojiyi uzun y1llar kullanma potansiyeline sahip olan ortaokul öğrencilerinin görüşlerinin belirlenmesi ve öğrenme aktivitelerine bu şekilde yön verilmesi önemli görülmektedir. $\mathrm{Bu}$ sayede öğrenme sürecini olumlu etkileyen ve etkili SG uygulamalarının tasarlanabileceği düşünülmektedir. $\mathrm{Bu}$ bağlamda mevcut araştırma kapsamında da ortaokul öğrencilerinin SG teknolojilerinin kullanım süreçlerine ve kullanım 
tercihlerine yönelik görüşlerinin belirlenmesi amaçlanmıştır. Bu amaç doğrultusunda aşağıda belirtilen araştırma sorularının cevapları aranmıştır.

1. Katılımcılar SG teknolojilerini nasıl tanımlamaktadırlar? $\mathrm{Bu}$ tanımlarda öne çıkan kavramlar nelerdir?

2. Katılımcıların SG teknolojilerinin kullanılabileceği alanlara yönelik görüşleri nelerdir?

3. Katılımcıların öğretimsel amaçlı olarak SG teknolojilerinin kullanılabileceği derslere yönelik görüşleri nelerdir?

4. SG teknolojilerinin kullanımı katılımcılar üzerinde ne tür duygu değişimlerine sebep olmaktadir?

5. Katılımcılara göre SG teknolojilerinin üstün yönleri ve sınırlılıkları nelerdir?

6. Katılımcıların SG teknolojilerini gelecekte kullanmaya yönelik tercihleri nelerdir?

7. Katılımcılar SG teknolojileri için geliştirilen farklı içerik türleri arasındaki tercihler ne yöndedir?

\section{Yöntem}

SG teknolojilerinin ortaokullarda kullanım süreçlerinin ve kullanım tercihlerinin incelenmesi amaçlanan bu araştırmada nitel araştırma yöntemlerinden biri olan durum çalışması yöntemi tercih edilmiştir. Alanyazında durum çalışmalarının mevcut bir durum çerçevesinde derinlemesine bilgi edinilmesinin gerekli olduğu durumlarda tercih edilerek araştırmacıya durumu derinlemesine araştırma imkanı sunan bir yapıya sahip olduğu belirtilmektedir (Merriam, 2009). Bu bağlamda durum çalışmasının tercih edilmesinde özellikle katılımcıların SG teknolojilerine yönelik görüşleri almak ve bu görüşlerin altında yatan nedenleri ayrıntılı olarak incelenmek istenmesinin önemli bir etkisi bulunmaktadır. Derinlemesine bilgi edinmeyi sağlayan durum çalışması yönteminin kullanıldığı bilgi toplanması için grubun tüm katılımcılarına ulaşmak yerine daha küçük bir grubun araştırmaya dâhil edilebileceği belirtilmektedir (Büyüköztürk, Çakmak, Akgün, Karadeniz ve Demirel, 2010). Mevcut araştırma kapsamında da öğrenenlerin SG kullanım deneyimleri ve kullanım tercihlerine yönelik görüşleri ayrıntılı olarak incelenmek istediğinden ve var olan durum kendi şartları içinde araştırıldığından dolayı durum çalışması en uygun yöntem olarak görülmüştür.

\section{Çalışma Grubu}

Bayburt ilinde öğrenim gören ortaokul öğrencilerinden oluşan 10 erkek ve 19 kız toplam 29 katılımcı çalışma grubuna dâhil edilmiştir. Çalışma gurubunun seçiminde amaca uygun örnekleme yöntemi tercih edilmiştir. Amaca uygun örnekleme, zengin bilgiye sahip olunduğu düşünülen durumların derinlemesine incelenmesine olanak tanıyan bir seçim yöntemidir (Yıldırım ve Şimşek, 2006). Cochran (1977) amaca uygun örneklemede araştırma yapılacak 
grubun kolay erişebilir ve araştırma için hazır olduğunu belirtmektedir. Ayrıca amaca uygun örneklem seçim yönteminde gönüllülük esastır ve katılımcıların süreç içinde araştırmaya istekli olmaları gerekmektedir (Kish, 1995). Ancak amaca uygun örneklem seçim yönteminde araştırmacı yeterince temsil gücü olmadığı için örneklemi evrene genelleme yapmak için kullanmaz (Lohr, 1999). Katılımcıların araştırma sürecine gönüllü olarak destek vermesine dikkat edilerek çalışmanın bütün süreçlerinde bu ilke temel alınmıştır. Çalışma grubu Bayburt Milli Eğitim Müdürlüğü ile Bayburt Üniversitesi arasında gerçekleştirilen bir proje olan Çocuk Üniversitesi çalışması kapsamında Bayburt ili merkezdeki farklı okullarda öğrenim gören öğrencilerden oluşmaktadır. Bu proje kapsamında hem katılımcıların bağlı bulundukları kurum hem de aileleri gerekli izinleri çalışma gerçekleştirilmeden önce vermiştir. Ayrıca katılımcılarla yapılan görüşmeler ebeveynlerinin izinleri doğrultusunda gerçekleştirilmiştir. Çalışma grubu ortaokul kademesindeki tüm sınıfları (5., 6., 7., ve 8. sınıf) kapsamaktadır.

\section{Uygulama Süreci}

Uygulama sürecinde katılımcıların SG teknolojilerini tanımaları, özelliklerinden haberdar olmaları ve ilk kullanımdan kaynaklı olumlu veya olumsuz görüşlerinin ana çalışmayı etkilemesinin önüne geçebilmek amaciyla 2 hafta süren ve resim - video türlerindeki içerikler ile SG teknolojilerinin farklı kullanımlarının olduğu bir pilot çalışma yapılmıştır. Sunulan içerikler seçilirken öncelikle pilot çalışmada bütün öğrenenlerin ilgisini çekebilecek yaş seviyelerine uygun yaklaşık 3 dk'lık video türünden içerikler sunulmuştur. Buna ek olarak yine ilgili teknolojinin kütüphanesinde yer alan ve öğrencilerin daha önce görmedikleri yurtdışından manzara ve tarihi eser resimleri de gösterilmiştir. Bu uygulama da yaklaşık olarak $2 \mathrm{dk}$. sürmüştür. Pilot çalışma ana uygulamanın gerçekleştirileceği ortamda gerçekleştirilerek katılımcıların ortamı ve kendilerini rahat hissedebilecekleri düzeyde araştırmacıları tanımalarına özen gösterilmiştir. Bu pilot çalışmanın ardından katılımcılar ikişerli gruplar halinde birbirlerinden bağımsız olarak ayrılmış ve her bir katılımcıya aynı içerikler gösterilmiştir. Uygulama aşamasında öğrenenlere yine dikkatlerini ve ilgilerini içeriğe çekebilecek, yaş seviyelerine uygun yaklaşık $3 \mathrm{dk}$. 40 sn.’lik bir video gösteriminde bulunulmuştur. Her iki uygulamada da özellikle katılımcıların oturabilecekleri ve SG teknolojinde hareketi kolaylaştıran cihazla bütünleşik yön ve seçme tuşlarını rahat kullanabilecekleri ortamlar hazırlanmıştır. İçeriklerin yapısı dikkate alındığında uygulama sürecinde katılımcıların SG içeriklerini daha rahat takip edebilmeleri, düşme veya çarpma neticesinde herhangi bir kaza veya yaralanmaya maruz kalmamaları için kendi etrafinda $360^{\circ}$ 
dönebilen sandalyeler tercih edilmiştir. İçerik gösteriminde kullanıcının baş yapısına göre ayarlanabilen ve üzerinde kontrol tuşları olan SG gözlükleri kullanılmıştır. Hem pilot çalışmada hem de ana uygulamada aynı SG teknolojisi kullanılmıştır. Her bir katılımcı için SG cihazları kullanım için bir süre kısıtlaması getirilmemiş, katılımcılar istedikleri sürede istedikleri kadar aynı içerik içerisinde tekrarlar yaparak uygulama sürecini geçirmiştir. Uygulama sürecini tamamlayan katılımcılar ile gönüllük esasına göre görüşmeler yapılmıştır. Uygulama sürecine yönelik görseller Şekil 2’de sunulmuştur.
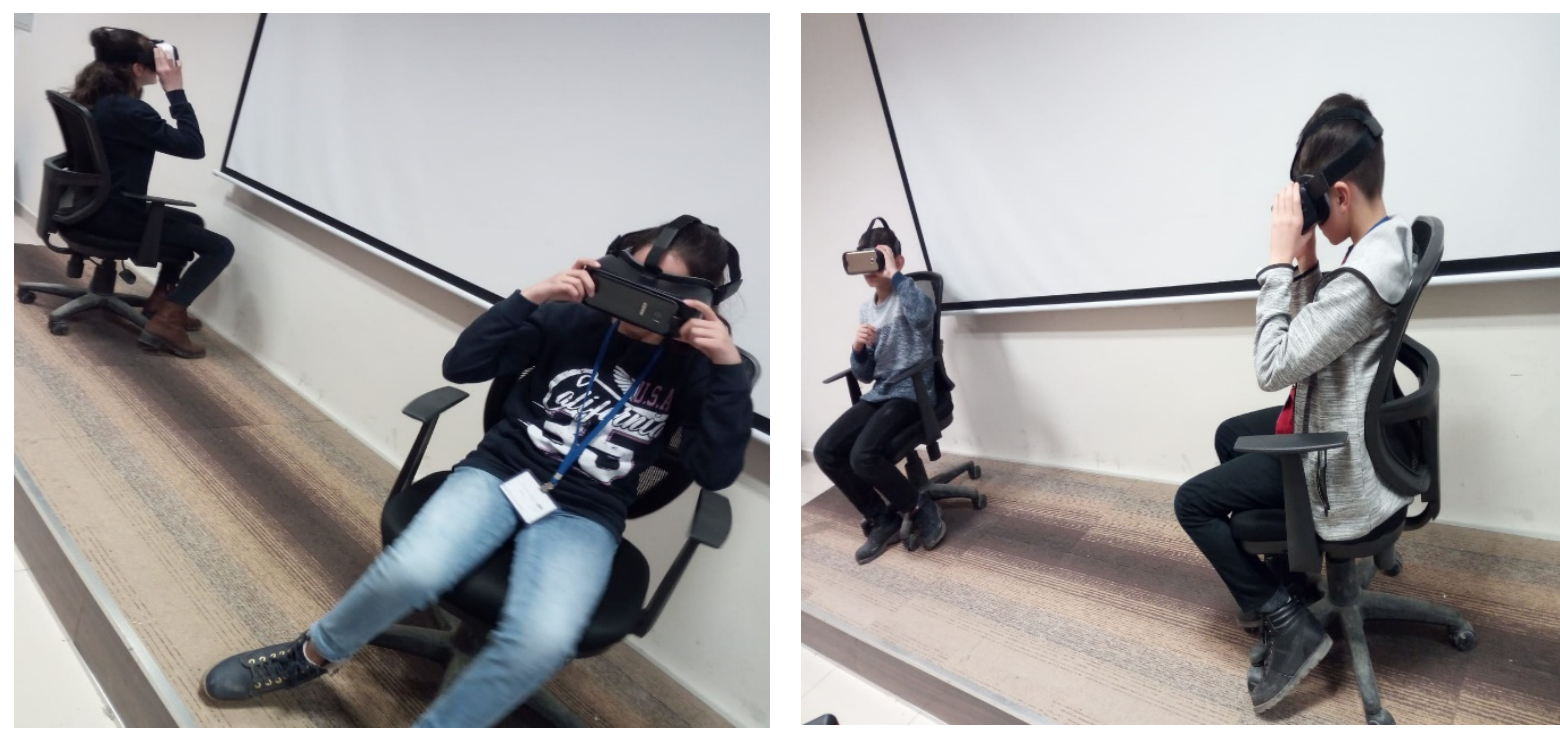

Şekil 2. SG uygulamalarında katılımcılara içerik gösterimi

\section{Verilerin Toplanması}

Mevcut araştırma kapsamında verilerin toplanmasında görüşme tekniği kullanılmıştır. Büyüköztürk ve diğ. (2010) tekniğin, bir konu hakkında derinlemesine bilgi toplamanın gerektiği durumlarda sıklıkla tercih edildiğini belirtmektedirler. Görüşme tekniği veri toplama sürecinde tek başına kullanılabileceği gibi diğer veri toplama araçları ile birlikte de kullanılabilir. Bu bağlamda araştırmacılar tarafından iki bölümden oluşan yarı yapılandırılmış bir görüşme formu hazırlanmıştır. Görüşme formunun ilk bölümünde uygulamadan önce katılımcıların SG teknolojilerine yönelik görüşleri almaya yönelik 3 soru yer almaktadır. İkinci bölümde SG teknolojisinin kullanım tercihlerini ve durumlarını ortaya çıkaracak 8 soru yer almaktadır. Görüşme formunun geçerliliğini sağlamak için alanda doktora derecesine sahip 3 uzmanın görüşleri alınmış ve Türkçe dil uzmanları tarafından ifade ve anlatım açısından görüşme formu kontrol edilmiştir. Veri toplama sürecinde pilot çalışma öncesinde katılımcıların SG teknolojisine yönelik yaklaşımlarını ve giriş düzeylerini ortaya çıkarmak için 
veri toplama aracının birinci bölümü ile 5-10 dk. arasında süren görüşmeler yapılmıştır. Pilot çalışma ve ana uygulamanın tamamlanmasının ardından katılımcılar ile tekrar görüşmeler yapılmış ve görüşme formunun hem birinci bölümü tekrar edilmiş hem de ikinci bölüm kullanılarak katılımcı görüşleri toplanmıştır. İkili görüşme anlayışı kullanım öncesinde ve sonrasında SG teknolojilerine yönelik katılımcıların görüşlerinde ortaya çıkabilecek muhtemel değişimleri ortaya çıkarmak için benimsenmiştir. Gönüllülük esasına göre görüşmeler gerçekleştirilmiş ve katılımcıların izinleri doğrultusunda ses kayıt cihazı yardımıyla görüşmeler kayıt altına alınmıştır.

\section{Verilerin Analizi}

Veri analizi sürecinde görüşme formundan elde edilen verilerin ayrıntılı bir şekilde incelenebilmesi için içerik analizi yöntemi kullanılmıştır. İçerik analizi, görüşme ve gözlem uygulamalarından elde edilen verilerin analizinde kullanılması uygun görülen bir analiz yöntemidir (Büyüköztürk ve diğ, 2010). Ayrıca içerik analizi; üzerinde çalışılan metinlerin düzenlenmesinde, sınıflandırılmasında, karşılaştırılmasında ve bu metinlerden teorik sonuçlar üretilmesinde etkili olan bir analiz tekniğidir (Cohen, Manion ve Morrison, 2007). Katılımcıların yarı yapılandırılmış bir görüşme formuna vermiş oldukları yanıtlara ilişkin ses kayıtları metne dökülmüştür. Konuşma metinleri, araştırma problemleri çerçevesinde kod, kategori ve analiz birimleri oluşturularak sayısal olarak betimlenmiştir. $\mathrm{Bu}$ işlemler gerçekleştirilirken kodlama güvenirliğini sağlamak için farklı araştırmacılar aynı görüşme kayıtları üzerinde çalışmıştır. Analiz sonucunda \%87 düzeyinde kodlama benzerliği sağlanmıştır. Kodlama güvenirliği, farklı kodlayıcıların aynı metni veya mesajı uyumlu şekilde kodlamalarına veya farklı zamanlarda aynı sonuçlara ulaşmasıyla sağlanmaktadır (Bilgin, 2014). Analiz sürecinin neticesinde kod, kategori ve tema yapıları çıkarılmış ve ilişkisel yapılar ortaya koyulmuştur.

\section{Sinırlılıklar}

Nitel araştırma yöntemlerinden olan Durum Çalışması deseni ile gerçekleştirilen bu çalışmanın sonuçları çalışma grubu ile sınırlıdır.

\section{Bulgular}


Ortaokul öğrencilerinin SG teknolojilerinin kullanım süreçlerine ve kullanım tercihlerine yönelik görüşlerinin belirlenmesi açısından görüşlerinin incelendiği mevcut araştırma kapsamında elde edilen bulgular aşağıda sırasıyla sunulmuştur.

\section{Katılımcılar SG teknolojilerini nasıl tanımlamaktadırlar? Bu tanımlarda öne çıkan kavramlar nelerdir?}

Katılımcıların görüşlerindeki değişimin incelenmesi için uygulamaya başlamadan önce ve uygulama sonunda SG teknolojilerinin kendilerine göre tanımını yapmaları istenmiştir. Katılımcıların büyük bir bölümünde SG teknolojilerini ve içerikleri tanımalarının bu teknolojiyi tanımlamalarında bir değişikliğe yol açmadığı ve katılımcıların uygulama başlamadan önce yapmış oldukları tanımların uygulama sonrasında da benzer olduğu görülmüştür $(\mathrm{N}=26$, \%89,6). Yapılan bu tanımlar büyük bir oranda teknolojinin özellikleri ifade etmektedir. Ancak üç katılımcının başlangıçta SG teknolojilerini diğer güncel teknolojilerle karıştırdığı ya da tanımlaya yapacak kadar fikir sahibi olmadıkları tespit edilmiştir. Bu üç katılımcıdan uygulama sonrasında elde edilen bulgulara göre tanımlama yapma düzeyine geldikleri görülmüştür $(\mathrm{N}=3$, \%10,4). SG teknolojilerini tanımlama bağlamda katılımcılar tarafından yapılan kişisel tanımlamalardan bazıları şöyledir.

Ö_1: Herhangi bir şeyi (gerçek olmayan veya içinde bulunmadiğımız bir yer vb.) teknoloji sayesinde gerçek gibi görmektir. Yani canl gibi gerçek.

Ö_10: Sanal gerçeklik insanın izlediği herhangi bir videonun içindeymiş gibi olması ve yaşamasıdır.

Ö_19: Sanal gerçeklik bizim sanal dünyayla iletişim kurmamızı sağlar. Gerçek hayattan dışarıdayız gibi sanal dünyada oluruz.

Ö_18: (Uygulamadan önce) 3 boyutlu makinenin çıtktısını alan bir sanal gerçeklik olabilir. (Uygulamadan sonra) Gerçek gibi gözüken bir sanaldır.

Ö_22: (Uygulamadan önce) Hologram olabilir. Bir cihazı alttan tutup onun üstündeki görüntüsüne sanal gerçeklik denir. (Uygulamadan sonra) Sanal gerçeklik insanin farklı açılardan görmesidir.

Ö_24: (Uygulamadan önce) Bilmiyorum. (Uygulamadan sonra) Bir oyunun, videonun ve resmin içine girmek.

Bulgular incelendiğinde uygulama sonunda tüm katılımcıların SG teknolojisi hakkında belirli düzeyde fikirlerinin oluştuğu görülmüştür. Her bir katılımcı teknolojinin veya uygulamaların özelliklerini ön plana çıkarmak suretiyle tanımlamalarda bulunmuştur. Katılımcıların kendi ifadeleri ile yaptıkları tanımlarda öne çıkan kodlar Tablo 1'de yer almaktadır.

Tablo 1 
SG Teknolojilerine Yönelik Yapılan Tanımlarda Öne Çıkan Kavramlar

\begin{tabular}{llc}
\hline Görüşler & Kat11ı̈c1lar & $f$ \\
\hline Gerçeklik hissi & Ö1, Ö3, Ö4, Ö5, Ö8, Ö9, Ö10, Ö11, Ö12, Ö14, Ö15, Ö16, Ö17, Ö18, & 19 \\
& Ö20, Ö21, Ö23, Ö25, Ö26, Ö29 & \\
İçeriğin 3B gösterimi & Ö6, Ö13, Ö15, Ö16, Ö17, Ö22, Ö24, Ö27, Ö28 & 4 \\
$\begin{array}{ll}\text { Eğlence arac1 } \\
\text { Gerçek dünyadan }\end{array}$ & Ö7, Ö9, Ö23, Ö28 & 2 \\
$\begin{array}{l}\text { sanala geçiş } \\
\text { Somutluk }\end{array}$ & Ö5 & 1 \\
\hline
\end{tabular}

Tablo 1 incelendiğinde katılımcıların SG teknolojilerini gerçeklik algısı ve hissedilen gerçek ortamda bulunma duygusu üzerinden tanımladıkları görülmektedir. Ayrıca SG teknolojilerinin herhangi bir içeriğin 3B gösterimlerine imkân tanıma özelliği ve kullanıcılarında oluşturduğu eğlence aracı olma durumları tanımlarda öne çıkan noktalar olarak karşımıza çıkmaktadır. Katılımcıların SG teknolojilerine yönelik ifade ettikleri tanımları gösteren örneklere aşağıda yer verilmiştir.

Ö_8: Gerçeklikve somutluk ...

Ö_10: Sanal gerçeklik insanın izlediği herhangi bir videonun içindeymiş gibi olması ve yaşamasıdır.

Ö_15: Teknolojik aletlerle bir eşyanın gerçek değil ama gerçekmiş gibi göstermek, canlı gibi olmasını sağlamaktır.

Ö_16: Bir ortamın görüntüsünü her tarafi görebilecek şekilde sanki oradaymıs gibi hissetmek.

Ö_19: Sanal gerçeklik gözlükleri bizim sanal dünyayla iletişim kurmamızı sağlar. Gerçek hayattan dışarıdayız gibi sanal dünyada oluruz.

Ö_23: Sanal gerçeklik eğlence, eğitim ve iş amacıyla kullanılan sanal ortamları gerçekmiş gibi yaşatan bir araçtır.

\section{Katılımcıların SG teknolojilerinin kullanılabileceği alanlara yönelik görüssleri nelerdir?}

Katılımcilardan SG teknolojilerini günlük hayatta hangi alanlarda kullanabileceklerini belirtmeleri istenmiştir. Görüşler incelendiğinde temelde eğlence ve eğitim alanları olmak üzere SG teknolojilerinin günlük hayatta birçok alanda kullanılabileceğini belirttikleri görülmüştür. Katılımcıların büyük bir bölümü SG teknolojilerinin kullanımı için tek bir alan ifade etmeyi tercih etmiş ve bu görüşler hem uygulama öncesi hem de uygulama sonrasında benzerlik göstermiştir. İki katılımcı $(\% 6,9)$ uygulama öncesinde SG teknolojilerinin günlük yaşantıda kullanımına yönelik herhangi bir fikirlerinin olmadığını söylemişlerdir. Fikir beyan etmeyen katılımcılardan biri gerçekleştirilen uygulamadan sonra SG teknolojilerinin mimari ve eğitim 
alanında kullanılabileceğini söylemiştir. SG teknolojisinin günlük hayattaki kullanım alanlarına yönelik katılımcı görüşleri Tablo 2'de özetlenmiştir.

Tablo 2

SG teknolojilerinin kullanım alanlarına yönelik kullanıcı görüşleri

\begin{tabular}{lll}
\hline Görüşler & Kat1lımc1lar & $f$ \\
\hline Eğlence & Ö3, Ö5, Ö6, Ö7, Ö9, Ö11, Ö12, Ö13, Ö14, Ö15, Ö16, Ö17, Ö18, Ö19, & 19 \\
& Ö21, Ö23, Ö24, Ö27, Ö28 & 11 \\
Eğitim & Ö1, Ö2, Ö4, Ö9, Ö10, Ö12, Ö13, Ö15, Ö16, Ö20, Ö23 & 7 \\
Mimari & Ö1, Ö2, Ö7, Ö18, Ö20, Ö25, Ö29 & 5 \\
Meslek hayatında & Ö7, Ö10, Ö13, Ö15, Ö17 & 4 \\
Sağl1k & Ö7, Ö12, Ö16, Ö18 & 3 \\
Gezi & Ö8, Ö21, Ö27 & 2 \\
Illetişsim & Ö1, Ö21 & 3 \\
Hayatın her alanında & Ö25, Ö28, Ö29 & 2 \\
Fikrim yok & Ö20, Ö22 \\
\hline
\end{tabular}

Tablo 2'de görüldüğü üzere katılımcılar SG teknolojilerinin günlük hayatta genellikle eğlence amacıyla kullanılabileceğini düşünmektedirler. Bunun yanı sıra eğitim alanında ve mimari alanında da SG teknolojilerinin kullanılabileceği belirtilen görüşler arasındadır. Ayrıca katılımcılar ilerde meslek hayatlarında, sağlık sektöründe, gezi ve iletişim amacıyla da bu teknolojilerin kullanılabileceğini belirtmişlerdir. Bu durum ile ilgili örnek katılımcı görüşlerine aşağıda yer verilmiştir.

Ö_4: Öğrenmemiz gereken bilgileri gerçekten yapıyormuş gibi öğrenmekte kullanılabilir.

Ö_9: Bence canımız sıkılınca ĕglence amaçlı ya da hayal ettiğimiz ama yapamadiğımız şeyleri gerçekleştirmek için kullanılabilir.

Ö_19: Oyunlarda daha gerçekçilik yaratmak için. Video izlerken videonun içinde kendimizi hissetmek için.

Ö_21: Başka birini özlediysek sanal gerçeklikle sanki onunla birlikteymiş gibi kullanabiliriz. Macera alanlarında ya da bir yere gitmek istediysek ve gidemediysek kullanabiliriz...

Ö_28: Lyi amaçlarda kullanılırsa bütün alanlarda kullanılabilir.

\section{Katılımcıların öğretimsel amaçlı olarak SG teknolojilerinin kullanılabileceği derslere yönelik görüşleri nelerdir?}

Çalışma kapsamında SG teknolojilerin hangi derslerde kullanılabileceğine yönelik uygulama öncesinde ve sonrasında katılımcı görüşleri alınmıştır. Bu bağlamda katılımcıların büyük çoğunluğu uygulama öncesinde sunmuş oldukları ders isimlerini uygulama sonrasında da benzer şekilde belirtmişlerdir. Ancak bazı katılımcılar uygulama sonrasında SG teknolojilerinin bütün derslerde kullanılabilecek bir teknoloji olduğunu belirtmişlerdir. 
Katılımcılar tarafından ifade edilen SG teknolojisi kullanılabilecek derslerin listesi Tablo 3'te yer almaktadir.

Tablo 3

SG teknolojilerinin kullanılabileceği derslere yönelik kullanıcı görüşleri

\begin{tabular}{llll}
\hline Dersler & & Kat11mc1lar & $f$ \\
\hline & Bilişim & Ö3, Ö4, Ö5, Ö7, Ö11, Ö14, Ö15, Ö16, Ö17, Ö19, Ö20, Ö22, & 13 \\
& Teknolojileri & Ö24 & \\
\hline Fen & Biyoloji & Ö2, Ö8, Ö9, Ö10, Ö13, Ö15, Ö16, Ö21, Ö25, Ö26, Ö28, Ö29 & 12 \\
Bilimleri & Kimya & Ö1, Ö8, Ö16, Ö25, Ö28 & 5 \\
& Fizik & Ö8, Ö16, Ö25, Ö28 & 4 \\
\hline Sosyal & Tarih & Ö1, Ö2, Ö8, Ö16, Ö21, Ö25, Ö29 & 7 \\
Bilimler & Coğrafya & Ö2, Ö8, Ö9, Ö16, Ö25, Ö27 & 6 \\
\hline & Matematik & Ö10, Ö16, Ö25 & 2 \\
& Türkçe & Ö5, Ö14 & 2 \\
& Astronomi & Ö8, Ö27 & 1 \\
& Resim & Ö26 & 7 \\
& Bütün Dersler & Ö1, Ö2, Ö6, Ö9, Ö12, Ö18, Ö23 & 2
\end{tabular}

Tablo 3'te de görüldügü üzere katılımcılar SG teknolojilerinin hemen hemen bütün derslerde kullanılabileceğini belirtmişlerdir. Özellikle teknoloji kullanımını vurgulanarak SG uygulamalarının bilişim teknolojileri dersine daha uygun olabileceği belirtilmiştir. Bunun yanı sıra özellikle fen bilimleri alanında SG teknolojilerinin etkili olabileceği ifade edilmiştir. Ayrıca sosyal bilgilerde de SG teknolojilerinin derslerine yardımcı olabileceğini belirttikleri görülmüştür. Bunun haricinde matematikten resim dersine kadar faklı alanlarda da kullanılabileceği katılımcıların görüşleri arasındadır. SG teknolojilerinin kullanım alanı olabilecek muhtemel derslere yönelik örnek katılımcı görüşlerine aşağıda yer verilmiştir.

Ö_1: Fen bilimleri dersinde deney yaparken sanal gerçeklik ile bir kimyasal $v b$. kullanmadan deney yapilabilir. Sosyal bilgiler dersinde Kültür ve Miras konusunda Türkiye'yi gezerek (sanal gerçeklik ile) görerek öğreniriz.

Ö_9: Kullanılabilir. Mesela biz nesli tükenmiş hayvanları göstermek istiyoruz. Sanal gerçekliği (SG) kullanabiliriz ve böylece nesli tükenmiş hayvanları görebiliriz. Ya da herkese tanıtmak istediğimiz bir ülkeyi gösterebiliriz.

Ö_13: Bence kullanılabilir. Mesela fen dersinde konumuz vücudumuzsa o zaman sanal gözlüğ̈̈ takınca sanki vücudumuzda gezinti yapıyormuşuz gibi olur.

Ö_20: Bilişim teknolojileri dersinde kullanılabilir. Çünkü çok fazla bilgisayarla işimiz oluyor ve bazen canl görmemiz gereken şeyler oluyor.

Ö_21: Fen dersinde vücut ve dolaşım konusunda kullanılabilir. Vücut konusunda eklemler, kaslar, iskelet, kan dolaşımı ... vb. şeyler sanal gerçeklikle kullanılıp daha iyi anlayabiliriz. Sosyal bilgiler dersinde de kullanılır. O zamanki savaşları yakından görebiliriz. 
Ö_26: Resim dersinde kullanılabilir. Çünkü sahte bir ortamda olanları hayal gücümüzle birleştirip güzel bir resim ortaya koyabiliriz. Fen bilimleri dersinde kullanılabilir. Çünkü canlılar ve dünya akılda daha kalıcı kalır ve konu pekişir.

Ö_27: Fen bilimleri dersinde kullanılabilir. Çünkü gezegenler, uzay vb. gibi konularda bazen somut bir gerçeğe varllmak istenebilir. Bu nedenle sanal gerçeklik bu konuda daha iyi olabilir.

Sosyal bilgiler dersinde kullanılabilir. Çünkü bitki örtülerinden veya coğrafi yerlerden bahsederken orayı görmek daha etkili olabilir. Bu nedenle sanal gerçeklik kullanılabilir.

\section{SG teknolojilerinin kullanımı katılımcılar üzerinde ne tür duygu değişimlerine sebep olmaktadır?}

Çalışma kapsamında SG teknolojilerinin kullanım deneyiminin yansımalarına odaklanılmıştır. Bu bağlamda katılımcılar üzerindeki etkisini belirlemek uygulama sonrasında SG teknolojinin kullanımının nasıl duygular oluşturduğu sorulmuştur. Katılımcılarından elde edilen görüşlere göre kategorize edilen bulgular Tablo 4’te sunulmuştur.

Tablo 4

SG teknolojilerinin kullanıcılar üzerinde oluşturduğu duygu değişimleri

\begin{tabular}{lll}
\hline Görüşler & Kat111mc1lar & $\mathrm{f}$ \\
\hline $\begin{array}{l}\text { Ortamda } \\
\text { hissi }\end{array}$ bulunma & Ö2, Ö3, Ö4, Ö8, Ö9, Ö11, Ö12, Ö13, Ö14, Ö15, Ö17, Ö18, Ö19, Ö20, & 19 \\
Heyecan & Ö21, Ö23, Ö26, Ö28, Ö29 & \\
& Ö1, Ö4, Ö6, Ö10, Ö12, Ö13, Ö15, Ö16, Ö19, Ö20, Ö21, Ö22, Ö24, & 15 \\
Mutluluk & Ö27, Ö29 & \\
Merak & Ö6, Ö8, Ö14, Ö15, Ö17, Ö18, Ö19, Ö22, Ö25, Ö27, Ö28, Ö29 & 12 \\
Farkl1 bir deneyim & Ö9, Ö24, Ö27 & Ö2, Ö7, Ö26 \\
Korku & Ö5, Ö8, Ö10, Ö11, Ö13, Ö18 & 1 \\
\hline
\end{tabular}

Tablo 4’te de görüldüğü gibi katılımcılar SG teknolojilerinin kendilerinde genellikle olumlu hisler oluşturduğunu belirtmişlerdir. Katılımcılar uygulama süresince SG teknolojilerinin kendilerini gerçek dünyadan çıkarıp uygulamanın geçtiği ortamın bir parçası gibi hissettirdiğini vurgulamışlardır. Bunun yanı sıra süreç içinde çok fazla heyecanlandıkları ve mutlu oldukları da belirtilen görüşler arasındadır. Ayrıca SG teknolojilerinin farklı bir deneyim sunduğu ve buna bağlı olarak merak duygularının da oluştuğu vurgulanan görüşler arasındadır. Ancak bazı katılımcılar özellikle uygulama sürecinde bazı durumların korkutucu olduğunu ve buna bağlı olarak da endişelendiklerini ifade etmişlerdir. Ancak korku hissinin uygulama devam ettikçe azaldığını ve geçtiği belirtilmiştir. SG teknolojisinin katılımcılarda oluşturduğu duygular ile ilgili örnek görüşlere aşağıda yer verilmiştir.

Ö_4: Sanki içindeymişim gibi hissettiriyor.

Ö_5: Biraz korktum. Üstümden araba atladl. 
Ö_8: Yüksekten biraz korktum ama videonun içindeymiş gibi hissettim. Sevinç ve korku.

Ö_12: Sanal gerçeklik bana acayip hissettirdi. Kendimi gerçekten o ortam içinde hissettim. Böyle nasll anlatsam yani heyecanl, aksiyonlu ... gibi duygular hissettim.

Ö_15: Sanal gerçeklik beni çok mutlu hissettirdi. Videoyu izlerken kendimi zannettim ki araba gidiyor ben de onun yanındayım. Zannettim ki araba beni ezecek ama video çok güzeldi, heyecanlandım.

Ö_16: Çok güzeldi. Ben önceden izlemişstim. Şimdi sıkılırım dedim ama izledikten sonra fikrim değişti.

Ö_27: Çok mutlu ve şaşkın hissettim. Çünkü hiç tanımadiğım yerlerde olmak oldukça ilginçti.

\section{Katılımcılara göre SG teknolojilerinin üstün yönleri ve sınırlılıkları nelerdir?}

Çalışma kapsamında uygulama sonrasında katılımcıların SG teknolojilerinin üstün yönlerini ve sınırlılıklarına yönelik görüşleri irdelenmiştir. Tablo 5'te katılımcıların SG teknolojisinin üstün yönlerine yönelik görüşleri yer almaktadır.

\section{Tablo 5}

Katılımcılara göre SG teknolojilerinin üstün yönleri

\begin{tabular}{llc}
\hline Görüşler & Kat1lımc1lar & $f$ \\
\hline Etkili öğrenmeyi sağlama & Ö1, Ö2, Ö5, Ö6, Ö11, Ö12, Ö13, Ö15, Ö16, Ö18, Ö21, & 16 \\
& Ö23, Ö24, Ö25, Ö26, Ö28 & \\
Eğlenceli öğrenme ortamları sunma & Ö2, Ö6, Ö9, Ö10, Ö19, Ö23 & 6 \\
Öğrenme yaşant1larını kolaylaştırma & Ö7, Ö8, Ö14, Ö16, Ö17, Ö27 & 4 \\
$\begin{array}{l}\text { Gözlenmesi zor veya imkansız } \\
\text { durumları öğretme }\end{array}$ & Ö9, Ö13, Ö22, Ö29 & \\
$\begin{array}{l}\text { Hayal gücü geliştirme } \\
\text { Olumlu etkisi olmaz }\end{array}$ & Ö8 & 1 \\
\hline
\end{tabular}

Tablo 5'te görüldüğ̈̈ üzere katılımcılar, SG uygulamalarının en olumlu yanının etkin öğrenme imkânı sağlaması olarak ifade etmişlerdir. Bu bağlamda mevcut teknolojinin etkili öğrenmenin gerçekleşmesinde önemli olduğu vurgulanmıştır. Bunun yanı sıra öğrenme ortamlarının daha eğlenceli olmasında ve öğrenme yaşantılarının daha kolay gerçekleşmesinde SG teknolojilerinin etkili olduğu belirtilmiştir. Ayrıca gözlenmesi imkansız veya zor olan durumların da SG teknolojileri sayesinde rahatça gerçek yaşam deneyimlerine uygun bir şekilde gözlenmesinin mümkün olduğu belirtilen görüşler arasındadır. SG teknolojisinin üstün yönleri ile ilgili örnek katılımcı görüşlerine aşağıda yer verilmiştir.

Ö_2: Daha iyi ve e ğlenceli bilgi edinirim.

Ö_6: Dersleri daha iyi kavrayabilirim. Onunla ĕglenip öğrenebilirim. 
Ö_22: Gidemediğimiz yerlere gitme imkanı doğmuş olur.

Ö_26: Her ş̧ey gerçekçi olduğu için gördügümüz derslerin videolarını böyle izlesek her şey somutlaşır ve akılda daha kalıcı olur.

Çalışma kapsamında katılımcılardan SG teknolojilerinin sınırlılıklarına yönelik görüşlerini belirtmeleri istenmiştir. Katılımcılar sınırlılık noktasında genellikle sağlık ve bağımlılık gibi durumların ön plana çıkarmakla birlikte herhangi bir sınırlılığının olmadığını belirten birçok katılımcının varlığı dikkat çekmiştir. SG teknolojilerinin sınırlılıklarına yönelik katılımcı görüşleri Tablo 6'da yer almaktadır.

Tablo 6

Katılımcılara göre SG teknolojilerinin sınırlılıkları

\begin{tabular}{llc}
\hline Görüşler & Kat1lımc1lar & $f$ \\
\hline Teknoloji ve internet bağımlılı̆̆ına sebep olma & Ö2, Ö6, Ö8, Ö9, Ö10, Ö27 & 6 \\
Göz bozma & Ö7, Ö17, Ö19, Ö29 & 4 \\
S1k kullanımda akademik başarıya olumsuz etki & Ö7, Ö9, Ö20 & 3 \\
Gerçek hayattan soyutlama & Ö1, Ö5 & 2 \\
Sosyal çevreye zarar verme & Ö6, Ö9 & 2 \\
Baş dönmesine sebep olma & Ö23, Ö26 & 2 \\
Pahalı olmas1 & Ö10 & 1 \\
Gezinti halinde kullanamama & Ö13 & 1 \\
Kir1lma ihtimali yüksekliği & Ö15 & 1 \\
Zaman kaybına sebebiyet verme & Ö16 & 1 \\
Her derse uygun olmama & Ö18 & 1 \\
Herhangi bir sinırl11ı̆̆1 bulunmamakta & Ö3, Ö11, Ö12, Ö14, Ö21, Ö22, Ö24, Ö25, & 9 \\
& Ö28 & \\
\hline
\end{tabular}

Tablo 6'da görüldüğü gibi katılımcıların arasında en öne çıkan görüş SG teknolojilerinin herhangi bir olumsuz yönünün bulunmadığıdır (\% 27). Bunun yanı sıra mevcut teknolojinin bir bağımlılığa sebebiyet verebileceği ve çeşitli sağlık problemlerinin oluşmasına neden olabileceği (baş dönmesi, göz bozulması gibi) öne çıkan sınırlılıklar arasındadır. Bunun yanı sıra birkaç katılımcı açısından SG teknolojilerinin sık kullanımında akademik başarı üzerinde olumsuz etki oluşturabileceği ve bireyleri gerçek hayattan uzaklaştırabileceği de düşünülmektedir. Ayrıca SG teknolojilerinin maliyeti ve cihazların kırılgan yapısı da belirtilen sınırlılıklar arasındadır. SG teknolojilerinin sınırlılıkları ile ilgili örnek katılımcı görüşlerine aşağıda yer verilmiştir.

Ö_1: Gerçek hayattan koparıp sanal alana taşlyabilir.

Ö_6: Teknolojisi băğımlılı̆̆ı olabilir. Arkadaşlarımız azalabilir.

Ö_8: Her şeyin fazlası zararlıdır. Bağımlı kalabilirim ve hayal gücüm olduğundan fazla olabilir.

Ö_17: Gözlerimize zararı vardır. 
Ö_20: Kendimi oyunlara ve videolara kaptırip derslerimi ihmal edebilirim.

Ö_23: ... çok kullanırsam dengem bozulabilir.

\section{Katılımcıların SG teknolojilerini gelecekte kullanmaya yönelik tercihleri}

SG teknolojilerine yönelik katılımcıların belirttikleri olumlu ve olumsuz görüşlerden sonra mevcut teknolojiyi gelecekteki öğrenme yaşantılarında kullanmak isteyip istemedikleri sorgulanmıştır. Bu bağlamda katılımcılar Tablo 5'te belirtilen SG teknolojilerinin olumlu yönlerine atıf yaparak bu teknolojiyi gelecekteki öğrenme yaşantılarında kullanabileceklerini belirtmişlerdir (\% 96,5). Sadece bir katılımcı SG teknolojilerinin yaşantısına herhangi bir katkısı olmayacağını belirterek kullanmak istemediğini söylemiştir (\% 3,5). SG teknolojisinin gelecekteki kullanım tercihi ile ilgili örnek katılımcı görüşlerine aşağıda yer verilmiştir.

Ö_1: Evet. Çünkü ben görerek yaşayarak daha iyi öğreniyorum.

Ö_8: İsterim. Derslere daha iyi odaklanabilir ve daha iyi anlayabilirim.

Ö_10: Tabi ki isterim ... derse de olsun hayal gücüne de olsun katkları olur. Belki hayal gücümüzle başka şeyler yapabiliriz.

Ö_13: Isterim. Dersler bazen sıkıcı oluyor. O zaman sanal gerçeklik kullanırdık. Çok eğlenceli olurdu. Bana 3D görünüm olur ve çok daha iyi öğrenirim.

Ö_21: Bence kullanılması lazım. Korkularımızı yenmeye yardımcı olur.

Ö_27: Kullanılmasını isterim. Çünkü bana merak ettiğim veya araştırmam gereken yerlerde çok yardımcı olabilir.

Ö_20: Hayır istemem. Katkısı olacăğnı sanmıyorum.

7. Katılımcılar SG teknolojileri için geliştirilen farklı içerik türleri arasındaki tercihler ne yöndedir?

Çalışma kapsamında katılımcılardan SG ortamlarında sunulan farklı türden (oyun, video veya resim) içeriklerden hangilerini daha fazla tercih edeceklerini belirtmeleri istenmiştir. Bulgular incelendiğinde özellikle oyun türünden içeriklerin daha fazla tercih edildiği görülmüştür. Bunun yanı sıra video ögelerinin de tercih durumları oldukça yüksektir. Ancak resim türünden içeriklerin SG ortamlarında katılımcılar tarafından çok fazla tercih edilmediği görülmüştür. Ayrıca cinsiyet durumuna göre SG öge tercih durumu incelendiğinde erkeklerin ve kızların en çok oyunları tercih ettikleri görülmüştür. Erkeklerin tamamı (\%100) kızların ise yaklaşık \%63'ü oyun türünden içerikleri daha çok tercih ettiklerini belirtmişlerdir. Bunun yanı sıra erkeklerin \%40’1 videoları tercih ederken kızların \%58'i bu türden içerikleri kullanmak istediklerini belirtmişlerdir. Resim türünden içeriklerde de hem erkeklerin hem de kızların sadece \%10'u bu türden içerikleri tercih etiklerini belirtmiş̧lerdir. SG teknolojilerinde sunulan içeriklerin tercih durumlarına yönelik katılımcıların görüşleri Tablo 7'de sunulmuştur.

\section{Tablo 7}


Katılımcıların en çok tercih ettiği SG içerik türleri ve tercih etme nedenleri

\begin{tabular}{|c|c|c|c|c|c|}
\hline $\begin{array}{l}\text { İçerik } \\
\text { Türleri }\end{array}$ & Katılımcılar & Görüşler & $f$ & $\mathrm{~K} 1 \mathrm{z}$ & Erkek \\
\hline Oyun & $\begin{array}{l}\text { Ö1, Ö3, Ö4, Ö5, Ö6, Ö8, Ö9, Ö10, Ö11, } \\
\text { Ö15, Ö16, Ö17, Ö19, Ö20, Ö21, Ö22, } \\
\text { Ö23, Ö24, Ö25, Ö27, Ö28, Ö29 }\end{array}$ & $\begin{array}{ll}\text { - } & \text { Eğlenceli } \\
\text { - } & \text { Oyun oynamayı sevmek } \\
\text { - } & \text { Gerçekçi } \\
\text { - } & \text { Heyecan verici }\end{array}$ & 22 & $\begin{array}{c}12 \\
(\% 63)\end{array}$ & $\begin{array}{c}10 \\
(\% 100)\end{array}$ \\
\hline Video & $\begin{array}{l}\text { Ö2, Ö6, Ö7, Ö12, Ö13, Ö14, Ö15, Ö16, } \\
\text { Ö18, Ö19, Ö20, Ö25, Ö26, Ö28, Ö29 }\end{array}$ & $\begin{array}{ll} & \text { Eğlenceli } \\
\text { - } & \text { Heyecan verici } \\
\text { - } & \text { Yaygın } \\
\text { - } & \text { İzlemesi rahat } \\
\text { - } & \text { Video izlemeyi sevmek } \\
\end{array}$ & 15 & $\begin{array}{c}11 \\
(\% 58)\end{array}$ & $\begin{array}{c}4 \\
(\% 40)\end{array}$ \\
\hline Resim & Ö20, Ö22, Ö29 & - $\quad$ Etkileyici & 3 & $\begin{array}{c}2 \\
(\% 10) \\
\end{array}$ & $\begin{array}{c}1 \\
(\% 10)\end{array}$ \\
\hline
\end{tabular}

Tablo 7'de görüldüğü gibi katılımcılar SG ortamlarda en fazla oyun türü içerikleri tercih etmektedirler. Katılımcılar, özellikle oyunun içindeymiş gibi hissetmenin oldukça eğlenceli olduğunu belirtmiştirler. Bunun yanı sıra katılımcılar günlük hayatta da oyun oynamayı sevdiklerinden dolayı SG ortamlarında da oyun oynamanın daha iyi olacağını düşünmektedirler. Ayrıca oyunların daha heyecan verici ve daha gerçekçi olabileceği için bu türden içeriklerin daha fazla tercih edilebileceği belirtilmiştir. Oyun içeriklerinin tercihi ile ilgili örnek katılımcı görüşlerine aşağıda yer verilmiştir.

Ö_1: Oyun çünkü oyunun içinde olmak eğlenceli olabilir.

Ö_5: Oyun. Hep oyun oynamayı sevdiğim için.

Ö_11: Oyun. Çünkü daha gerçekçidir.

Ö_21: Oyun olurdu. Çünkü oynarken kendin içinde olursun, heyecanlanırsın.

Video ögelerinin kullanımını tercih edeceklerini belirten katılımcılar özellikle bu türden ögelerin daha eğlenceli ve heyecan verici olabileceklerine dikkat çekmişlerdir. Ayrıca SG ortamlarından video ögelerinin izlenmesinin daha kolay olabileceği ve bu ögelere daha rahat ulaşılabileceğinin düşünülmesi de tercih nedeni üzerine etkili olmuştur. Ayrıca bazı katılımcılar da günlük hayatlarında da video izlemekten hoşlandıklarından dolayı bu ögelerini daha fazla tercih edeceklerini belirtmişlerdir. Video tercihlerine yönelik örnek katılımcı görüşlerine aşağıda yer verilmiştir.

Ö_2: Video çünkü hem çok yaygın hem de daha eğlenceli.

Ö_12: Video çünkü daha heyecanll.

Ö_14: Bence video. Çünkü video izlerken daha eğlenceli oluyor. Diğerleri bana biraz daha sikicı geliyor.

Ö_26: Videoyu tercih ederdim. Çünkü resim çok tekdüze olurdu. Oyunlardan hoşlanmiyorum. 
Resim türünden içerikleri tercih eden katılımcıların sayıları diğerlerine göre oldukça sınırlı kalmıştır. Bu bağlamda resim türünden içerikleri tercih edenler özellikle etkileyici resimlerin olabileceği üzerine odaklanmışlardır. $\mathrm{Bu}$ durum ile ilgili örnek katılımcı görüşüneaşağıda yer verilmiştir.

Ö_22: Resim ve oyun. Çünkü resim etkileyici, oyun ise eğlenceli.

\section{Tartışma ve Sonuç}

Ortaokul öğrencilerinin SG teknolojilerinin kullanım süreçlerine ve kullanım tercihlerine yönelik görüşlerinin belirlenmesi amaçlandığı mevcut çalışma kapsamında katılımcıların günümüzde SG teknolojilerinin ortaokul seviyesindeki öğrenciler tarafindan tanındığı söylenebilir. Özellikle teknoloji ve teknolojinin yetkinliğine vurgu yapan tanımlar katılımcıların SG teknolojisinin yapısından haberdar olduğunu ortaya koymaktadır. Katılımcıların SG teknolojisinin tanınmasında günlük yaşantımızda bu teknolojinin yaygın hale gelmesinin ve çeşitli iletişim araçları vasıtasıyla sürekli tanıtılmasının önemli olduğu düşünülmektedir. Buna ek olarak SG teknolojilerinin maliyetinin son yıllarda düşmesi de bu teknolojilerin ulaşılabilirliğini artırmış ve kullanıcıların daha çok bilgi sahibi olmasını sağlamış olabilir (Jung, Dieck, Lee ve Chung, 2016). Ayrıca katılımcıların SG teknolojilerine yönelik tanımlamalarında özellikle gerçeklik hissi ve eğlence faktörlerinin ön plana çıktığ görülmektedir. Alanyazın incelendiğinde de SG teknolojilerine yönelik yapılan tanımlarda ve araştırmalarda da benzer noktalara dikkat çekildiği söylenebilir (Carrozzino ve Bergamasco, 2010; Çavas ve diğ., 2004; Rheingold, 1991). SG teknolojisinin temel felsefesinde eğlence olması bu vurgunun doğal olduğunu göstermektedir. Bununla birlikte katılımcıların üst düzey gerçeklik algısını oluşturması, SG teknolojisinin büyük potansiyelini ortaya koymaktadır. Bulunulması imkânsız olan ortamlar için oluşturulacak öğrenme yaşantılarının bu teknolojinin temelinde gerçekleştirilmesi daha etkin bir öğrenme yaşantısının kapısını açabilir.

Katılımcıların SG teknolojilerini günlük aktiviteler içinde kullanma isteği eğlence amaçlı uygulamaların ağırlıklı olduğu görülmüştür. Bu durumun oluşmasında katılımcıların yaş grupları ve teknolojinin temel üretim amacına yönelik kullanım isteği etkili olabilir. Benzer şekilde Başaran (2010) da SG teknolojilerinin eğlence ve turizm gibi farklı sektörlerde yaygın olarak kullanıldığını belirtmektedir. Katılımcılar SG teknolojilerinin eğitim alanında da kullanılabileceği görüşünde oldukları gözlenmiştir. Bu durum kendi öğrenme süreçlerinde böyle bir teknolojiyle sunulan içeriklerin daha etkin öğrenme yaşantılarıyla sonuçlanabileceği görüşlerinden kaynaklanıyor olabilir. Ayrıca katılımcıların yaş grupları düşünüldüğü zaman 
eğlenerek, ortam içerisinde var olma duygusunu yaşayarak öğrenmeyi tercih etmiş olabilirler. $\mathrm{Bu}$ bağlamda SG teknolojilerinin en çok tercih edilen eğitim ve eğlence alanlarının birleştirilmesi ile etkili öğrenme ve beceri veya etkileşim temelli ölçme değerlendirme ortamları oluşturulabileceği düşünülmektedir. Kayabaşı (2005) da SG teknolojilerinin öğretimsel amaçlı kullanımının etkili sonuçlar doğurabileceğini belirterek; bu teknolojilerin gelecekte yaparak yaşayarak öğrenme aktivitelerine imkan tanıyacağını ve etkili öğrenmelerin gerçekleştirilmesine aracılık edebileceğini belirtmiştir. Ayrıca SG teknolojilerinin iletişimden gezi alanına kadar birçok alanda da kullanılabileceği görülmüştür. Bu bağlamda mevcut teknolojinin gelişimi ile birlikte günlük hayatta bu teknolojilerin sıklıkla tercih edilebileceği ve birçok alanda etkili bir şekilde kullanılabileceği söylenebilir (Aslan, 2017).

Katılımcıların eğitim alanında kullanılabileceğini belirtikleri SG teknolojilerinin özellikle bilişim teknolojileri gibi teknoloji ağırlıklı derslerde sıklıkla kullanılabileceği vurguladıkları söylenebilir. Bunun yanı sıra fen bilimleri (biyoloji, kimya ve fizik) ve sosyal bilimler (tarih ve coğrafya) derslerinde de SG teknolojilerinin etkili olabileceğini vurguladıkları görülmüştür. Ayrıca matematikten astronomiye kadar birçok alanda da SG teknolojilerinin kullanımının önemli sonuçlar doğurabileceği de katılımcıların görüşleri arasındadır. Alanyazında da SG teknolojilerinin öğretimsel amaçlı olarak pek çok derste aktif bir şekilde kullanılabileceği belirtilmektedir (Aktamış ve Arıcı, 2013; Çavaş ve diğ., 2004; Kayabaşı, 2005; Subramanian ve Marsic, 2001). Yine gerçekleştirilen araştırmalarda sanal gerçeklik uygulamalarının öğrenenlerin akademik başarıları üzerinde olumlu bir etkiye sahip olduğu da vurgulanmaktadır (Aktamış ve Arıcı, 2013; Chen, Yang, Shen ve Jeng, 2007; Hudson, 2010). $\mathrm{Bu}$ derslerin belirtilmesinde özellikle mevcut derslerin zor olmasının ve somut öğrenme yaşantıları gerektirmesinin önemli olduğu görülmüsstür. Bakas ve Mikropuolus (2003) soyut kavramların somutlaştırılmasında SG teknolojilerinin etkili olduğunu belirtmektedir. Katılımcılar hakkında daha fazla bilgi edinmek istedikleri derslerde SG teknolojilerinin kullanımının daha etkili olabileceği vurguladıkları görülmüştür. Bu bağlamda özellikle ayrıntılı bilgi edinilmesi gerekli olduğu durumlarda veya somut öğrenme ortamlarının oluşturulmasında SG teknolojilerinin etkili olabileceği söylenebilir (Aguinas, Henle ve Beaty, 2001; Aktamış ve Aric1, 2013).

SG teknolojilerin öğrenenler üzerinde oluşturduğu duygular incelendiğinde mevcut teknolojiyi kullanan katılımcılar kendilerini sunulan ortamın içinde hissetmişlerdir. Yani bulundukları ortamdan farklı bir ortama geçtiklerini vurgulamışlardır. Üzümcü, Akın, Nergiz, 
İnözü ve Çelikcan (2018) gerçekleştirdikleri çalışmada SG teknolojilerini bireylerin duyularının yanıltılması neticesinde kendilerini üç boyutlu bir ortamın içindeymiş gibi hissetmelerine imkân tanıyan araçlar olarak tanımlayarak; başarılı bir sanal deneyimin sağlanabilmesi için kullanıcıların fiziksel olarak sanal ortamın içindeymiş gibi hissetmeleri gerekliliği üzerine odaklanmışlardır. Benzer şekilde Eryalçın (1994) SG teknolojilerinin en önemli amaçlarından birinin bireyleri bulunduğu ortamdan farklı bir ortama götürmek olduğunu belirtmiştir. Bunun yanı sıra heyecan, mutluluk ve merak SG teknolojisi kullanan katılımcıların en çok üzerinde durulan duygular olmuştur. İfade edilen bu duygular öğrenenleri harekete geçirecek ve içsel motivasyonu oluşturmanın altyapısını oluşturabilir. İçsel motivasyon etkin öğrenme yaşantılarının anahtarı olabilir. Bu açıdan bakıldığında mevcut teknolojinin bu avantajlarının öğrenme ortamlarında olumlu etkilere sahip olabileceği söylenebilir (Aslan, 2017). Ancak özellikle teknoloji ile ilk defa tanışan bireylerde uygulama başlangıcında bir korku hissinin oluştuğu da gözlemlenmiştir. Bu korku hissinin teknolojinin kullanımı ile birlikte ortadan kalktığı da söylenebilir. Bu bağlamda özellikle SG uygulamalarında teknolojinin olumlu özellikleri arasında yer alan bazı özellikleri dikkate alınarak geliştirilen veya var olan içeriklerin sunulmasının öğrenme yaşantıları üzerinde de olumlu etkilerin oluşmasında önemli olabilir. Öğrenme ortamlarında öğrenenlerin ilgi ve isteklerinin derse çekilmesinde SG teknolojilerin sunmuş olduğu iletişim ve etkileşim özelliklerin önemli olduğu düşünülmektedir. Aslan (2017)'da gerçekleştirdiği çalışmada SG uygulamalarının eğitimin her aşamasında kolaylıkla kullanılabileceğini belirtmiş ve bu teknolojilerin öğrenmeyi cazip ve kalıcı hale getirdiğini vurgulamıştır.

Katılımcılar SG teknolojilerinin olumlu yönlerini öğretimsel etkilerini ön plana çıkararak açıklamışlardır. Başka bir ifade ile katılımcılar SG teknolojilerini kullanan içeriklerin öğrenmelerini olumlu yönde etkileyeceğini düşünmektedirler. Bu bağlamda SG teknolojilerinin etkili ve eğlenceli öğrenme ortamları oluşturabileceği üzerinde en çok vurgu yapılan olumlu yönler öne çıkmaktadır. Çavaş ve diğ., (2004) SG teknolojilerinin öğrenenlerin motivasyonunu ve derse katılımını olumlu yönde etkilediğini belirtmektedir. Bu durum da eğlenceli öğrenme ortamlarının oluşturulmasına aracılık edebilir. Bunun yanı sıra gözlenmesi imkânsız durumları kolay bir şekilde gözlemleme imkânı sunması gibi üstünlüklerinin olduğu da belirtilen görüşler arasındadır. Benzer şekilde Aktamış ve Arıcı (2013) SG teknolojilerinin en olumlu yönlerinden birinin öğrenenlerin gerçek yaşamdaki tehlikelere maruz kalmadan gerçek yaşam deneyimlerini sanal ortamlarda güvenli bir şekilde kazanmaları olduğunu belirtmiştir. Ayrıca SG 
teknolojilerinin öğrenenlerin hayal gücünü geliştirebileceğine de çalışma sonucunda ulaşılan görüssler arasındadır. Bu durumun oluşmasında SG teknolojilerinin bireylerin günlük hayatta karşılaşamayacağ1 veya karşılaşma ihtimalinin çok zor olduğu durumlar için firsat sunarak bu durumlar üzerine tecrübe edinmesini sağlamasının önemli etkileri olabilir (Aktamış ve Arıcı, 2013). Bu tecrübe kazanımının bireyin hayal gücünü de olumlu yönde etkileyebileceği düşünülmektedir (Çavaş ve diğ., 2004).

SG teknolojilerinin olumlu yönlerinin yanı sıra bazı sınırlılıklarının da olabileceği de düşünülmektedir. $\mathrm{Bu}$ sınırlılıkları; sağlık, sosyal ve öğretimsel olarak sınıflandırmak mümkündür. Bu bağlamda SG teknolojilerinin sağlık alanında bağımlılık oluşturma potansiyeli ve göz sağlığı üzerine etkisi kullanıcıların en çok belirttikleri sınırlılıklar arasındadır. Bunun yanı sıra uzun süreli kullanımda baş dönmesine sebebiyet vermesi de belirtilen sınırlılıklar arasındadır. Benzer şekilde alanyazında da SG uygulamalarının sanal ortamlara dalmak, göz yorgunluğu, bulanık görme, baş ağrısı, oryantasyon bozukluğu, denge bozuklukları, uyuşukluk, terleme, iştahsızlık, bulantı ve kusma gibi semptomları içeren sopite sendromuna yol açabileceği de vurgulanmaktadır (Pierce ve Aguinis 1997; Regan ve Price 1994). Ayrıca Aslan (2017) da SG teknolojilerinin uzun süreli kullanımlarda baş dönmesi ve baş ağrısı gibi etkilerinin olabileceğini vurgulamıştır. Buna ek olarak sosyal anlamda SG teknolojileri bireylerin toplumdan ve gerçek hayattan soyutlanmasına ve arkadaş çevrelerinin azalmasına sebebiyet verebileceği söylenebilir. Ancak sağlık alanında yapılan bazı araştırmalarda da sosyal fobisi olan bireylerin SG uygulamaları ile birlikte bu fobilerinde azalmaların görüldüğü, topluluk önünde konuşma ve hitap etme özelliklerinin geliştiği de vurgulanmaktadır (Owens ve Beidel, 2015; Üzümcü ve diğ., 2018). Özellikle SG ortamlarında bireylerin bir avatar yardımıyla o ortamlarda bulunmaları ile gerçek yaşam koşulları gibi olmasa da dünya üzerinde farklı yerlerden de bireylerin arkadaş edinip sanal ortamda sosyalleşebileceği düşünülmektedir. Ayrıca Çavaş, Çavaş ve Can (2004) öğrenme ortamlarında SG teknolojilerinin sosyal bir atmosfer oluşturabileceğine dikkat çekmektedir. Bunun yanı öğretimsel açıdan SG teknolojilerinin sınırlılıkları incelendiğinde özellikle sürekli kullanımının akademik başarı üzerine olumsuz etkilerinin olabileceği, zaman kaybına sebep olabileceği ve her derse uygun içeriklerine sahip olamaması en temel sınırlılıklar arasında gösterilebilir. Ayrıca mevcut teknolojinin pahalı olması (Aguinas ve diğ., 2001) ve kırılma ihtimalinin bulunması da sinırlılıkları arasında gösterilebilir (Tax'en ve Naeve, 2002). Ancak bu durumun günümüzde teknolojinin gelişmesi ve yaygınlaşması ile birlikte değiştiği düşünülmektedir. Jung ve diğ. 
(2016) SG teknolojilerinde yaşanan gelişmeler ile birlikte bu araçların artık daha ucuz, kolay ve hızlı bir şekilde elde edilebileceğini vurgulamaktadır. Bunun yanı sıra yine alanyazında SG teknolojilerinin bazı teknik problemler (yenileme hızı düşüklüğü, internetin yavaş olması ve kullanıcı hareketleri ile görüntü arasındaki gecikme) nedeniyle kullanım aşamasında bazı sinırlılıklara sebebiyet verebileceği belirtilmektedir (Aslan, 2017).

SG teknolojilerine yönelik ortaokul öğrencilerinin oyun ve video türünden içerikleri daha fazla tercih ettikleri görülmüştür. Oyun türünden içeriklerin daha fazla tercih edilmesinde üzerinde çalışılan örneklemin yaş aralığının etkili olduğu düşünülmektedir. Ayrıca dijital nesil olarak tanımlanan $\mathrm{Z}$ kuşağı öğrenenlerinin teknolojiyi daha etkin kullanması ve öğrenme yaşantıları içinde bu araçlara sürekli yer vermesi geleneksel araçlardan ziyade teknoloji destekli ortamların daha fazla tercih edilmesinde etkili olduğu alanyazında belirtilmektedir (Karadoğan, 2019; Kennedy ve diğ., 2008; Ralender, 2014; Somyürek, 2014). Bu bağlamda oyun ve video ögelerinin de öğrenenler tarafından sık tercih edilmesinde günlük hayatta ve öğrenme yaşantılarında bu araçları sıklıkla kullanmaları ile ilgili olduğu düşünülmektedir. Yani öğrenenler aşina oldukları içerikleri daha fazla tercih etmişlerdir. Ancak resim türünden içerikler çok az kullanıcı tarafından tercih edilmektedir. Bu da resim türünden içeriklerin diğer içeriklere göre daha durgun ve az ilgi çekici olmasından kaynaklanmış olabilir. Genel olarak üzerinde çalışılan yaş grubu için özellikle oyun ve video içeriklerin öğretimsel amaçlı kullanımının öğretim yaşantılarını desteklemede de etkili olabileceği düşünülmektedir.

Sonuç olarak SG teknolojisi kullanıcısını gerçek ortamdan sanal bir ortama taşıma yetkinliğine sahiptir. Bu noktada teknolojinin gününü oluşturan temel bileşen olarak içerik ön plana çıkmaktadır. Özellikle bireysel kullanıma hitap eden yapısı olması SG teknolojilerinin sınıf içi kullanımlarını ve grup aktivitelerini olumsuz yönde etkilemektedir. Buna karşın bireysel öğrenme yaşantıları için eğlenceli, duygulara hitap eden ve içsel motivasyonu destekleyen içerikler ile etkin bir öğrenme ortamı olma potansiyeli bulunmaktadır. Eğlenceyi temel alan bu teknolojide en çok tercih edilen içerik türü de oyunlardır. Bu içeriklerin tercihini eğlenceli olmaları, kullanıcıların oyun oynamayı sevmelerinin, gerçekçi ve heyecan verici olmasın önemli etkilerinin olduğu söylenebilir. Benzer şekilde Aslan (2017) da SG teknolojilerinin en yaygın olarak eğlence sektöründe kullanıldığını vurgulamaktadır.

SG teknolojilerinin bireysel öğrenme yaşantılarını temel alan öğretim faaliyetlerinde kullanılabileceği ve uzaktan eğitim faaliyetleri için farklı alternatifler sunabileceği düşünülmektedir. Gelecekte araştırma yapacakların SG temelli bireysel öğrenme faaliyetlerini 
diğer bireysel öğrenme faaliyetleri ile etkililik, süre, kalıcılık gibi farklı değişkenler üzerinden değerlendirebilirler. Ayrıca sınıf ortamı ile sanal gerçeklik ortamlarının karşılaştırmaları da çeşitli araştırmalara konu edilebilir.

\section{Makalenin Bilimdeki Konumu}

Bilgisayar ve Öğretim Teknolojileri Eğitimi/Öğretim Teknolojileri

\section{Makalenin Bilimdeki Özgünlüğü}

Mevcut araştırma kapsamında SG uygulamalarının ortaöğretim düzeyinde kullanım deneyimleri incelenmiştir. Geleceğin öğrenme ortamlarını oluşturabileceği belirtilen (Kayabaşı, 2005) ve çok geniş bir kullanım alanına sahip olan SG teknolojilerinin öğrenme sürecine yeni başlayan bireyler açısından değerlendirilmesi önemli görülmektedir. Yeni bir teknolojinin öğrenme ortamlarına entegrasyonu genellikle bir süreç gerektirmekte ve bu süreçte de paydaşların mevcut teknolojiyi kabul ve kullanım durumları belirleyici rol almaktadır. Araştırma kapsamında SG teknolojilerinin uzun yıllar kullanıcısı olabilecek ortaöğretim öğrencilerinin SG teknolojilerine yönelik kullanım isteklerinin tespit edilmesinin, bu teknolojilerin üstün ve sınırlı yönlerinin belirlenmesinin ve öğretimsel amaçlı kullanım tercihlerinin belirlenmesinin alanyazına katkı sağlayacağı düşünülmektedir. Bu bağlamda $\mathrm{Z}$ kuşağı olarak adlandırılan mevcut grubun etkili yönlendirilmesi, desteklenmesi ve geliştirilmesi ülkemiz gelişimi üzerinde de olumlu etkilerin ortaya çıkmasına imkan tanıyacaktır (Karadoğan, 2019). Bunun akabinde mevcut araştırmanın geliştirilecek ortamların öğrenci görüşlerine göre şekillendirilmesinde önemli katkılarının olabileceği düşünülmektedir. Ayrıca SG teknolojilerine yönelik çalışmalar gerçekleştirilse de küçük yaş gruplarında görüş belirleme çalışmalarının sınırlı olduğu söylenebilir.

\section{Kaynaklar}

Aguinas, H., Henle, C. A., ve Beaty Jr, J. C. (2001). Virtual reality technology: A new tool for personnel selection. International Journal of Selection and Assessment, 9(1-2), 70-83.

Aktamış, H., ve Arıcı, V. (2013). Sanal gerçeklik programlarının astronomi konularının öğretiminde kullanılmasının akademik başarı ve kalıcılığa etkisi. Mersin Üniversitesi Ĕ̈itim Fakültesi Dergisi, 9(2), 58-70.

Alhalabi, W. (2016). Virtual reality systems enhance students' achievements in engineering education. Behaviour \& Information Technology, 35(11), 919-925.

Aslan, R. (2017). Uluslararası rekabette yeni imkânlar: sanal gerçeklik, artırılmış gerçeklik ve hologram. Ayrıntı Dergisi, 5(49). 
Bakas, C. ve Mikropoulos, T. A. (2003). Design of virtual environments for the comprehension of planetary phenomena based on students' ideas. International Journal of Science Education, 25, 949-467.

Başaran, F. (2010). Öğretmen adaylarının eğitimde sanal gerçeklik kullanımına ilişkin görüşleri (Sakarya Üniversitesi BÖTE örneği). YayınlanmamışYüksek lisans tezi, Sakarya Üniversitesi Sosyal Bilimler Enstitüsü, Sakarya

Bilgin, N. (2014). Sosyal bilimlerde içerik analizi: teknikler ve örnekler çalışmalar. Siyasal Kitabevi.

Büyüköztürk, Ş., Çakmak, E. K., Akgün, Ö. E., Karadeniz, Ş. ve Demirel, F. (2010). Bilimsel Araştırma Yöntemleri. Ankara: Pegem A Yayıncılık.

Carrozzino, M. ve Bergamasco, M. (2010). Beyond virtual museums: Experiencing immersive virtual reality in real museums. Journal of Cultural Heritage, 11(4), 452458.

Chavan, S. R. (2016). Augmented Reality vs. Virtual Reality: What are the differences and similarities?. Int. J. Adv. Res. Comput. Eng. Technol, 5(6), 1-6.

Chen, C. H., Yang, J. C., Shen, S., \& Jeng, M. C. (2007). A desktop virtual reality earth motion system in astronomy education. Journal of Educational Technology \& Society, 10(3), 289-304.

Civelek-Oruç, M., Yıldırım, İ. M., İmamoğlu, Ö., Demirel, G. ve Bilgin, M. B. (2017). Sanal Gerçeklik Uygulamalarının Müzelere Yansımaları: Ayasofya ve Louvre Müzelerinin Karşılaştırmalı Bir Analizi. In Eurasian Conference on Language \& Social Sciences(pp. 22-24).

Cochran, W. G. (1977). Sampling Techniques (Third ed.). Wiley.

Cohen, L., Manion, L. ve Morrison, K. (2007). Research methods in education (6th ed.). New York, NY: Routledge.

Çavas, B., Çavas, P. H. ve Can, B. T. (2004). Egitimde sanal gerceklik. TOJET: The Turkish Online Journal of Educational Technology, 3(4).

Eryalçın, B. (1994). Hayalle gerçeğin dansı sanal gerçeklik. Bilim Teknik, 27(323), 20-27.

Groves, M. M., \& Zemel, P. C. (2000). Instructional technology adoption in higher education: An action research case study. International Journal of Instructional Media, 27(1), 57.

Hudson, P. (2010). Educating EFL preservice teachers for teaching astronomy. Asia TEFL Conference, 6-8 Ağustos 2010, Hanoi University of Languages International Studies, Hanoi, Vietnam.

Jung, T., Dieck T., M. C., Lee, H. ve Chung, N. (2016). Effects of virtual reality and augmented reality on visitor experiences in museum. In Information and Communication Technologies in Tourism 2016 (pp. 621-635). Springer, Cham. 
Karadoğan, A. (2019). Z kuşağı ve öğretmenlik mesleği. A ̆grı İbrahim Çeçen Üniversitesi Sosyal Bilimler Enstitüsü Dergisi, 5(2), 9-41.

Kayabaşı, Y. (2005). Sanal gerçeklik ve eğitim amaçlı kullanılması. The Turkish Online Journal of Educational Technology, 4, 151-158.

Kennedy, G., Dalgarno, B., Bennett, S., Judd, T., Gray, K., \& Chang, R. (2008). Immigrants and natives: Investigating differences between staff and students' use of technology. Hello! Where are you in the landscape of educational technology, 484-492.

Kish, L. (1995). Survey Sampling, Wiley.

Lohr, S. L. (1999). Sampling: Design and Analysis. Duxbury.

Mann, S., Furness, T., Yuan, Y., Iorio, J. ve Wang, Z. (2018). All reality: Virtual, augmented, mixed (x), mediated (x, y), and multimediated reality. arXiv preprint arXiv:1804.08386.

Merriam, S. B. (2009). Qualitative Rssearch: A Guide to Design and Implemantation, JosseyBass. CA, USA

Nedas, T., Challacombe, B. ve Dasgupta, P. (2004). Virtual reality in urology. BJU international, 94(3), 255-257.

Nooriafshar, M., Williams, R. ve Maraseni, T. (2004). The Use Of Virtual Reality In Education, American Society of Business and Behavioral Sciences (ASBBS) 2004 Seventh Annual International Conference, 6-8 Aug 2004, Cairns, Australia.

Owens, M. E. ve Beidel, D. C. (2015). Can virtual reality effectively elicit distress associated with social anxiety disorder?. Journal of Psychopathology and Behavioral Assessment, 37(2), 296-305.

Pierce, C. A. ve Aguinis, H. (1997). Using virtual reality technology in organizational behavior research. Journal of Organizational Behavior: The International Journal of Industrial, Occupational and Organizational Psychology and Behavior, 18(5), 407-410.

Regan, E. C. ve Price, K. R. (1994). The frequency of occurrence and severity of side-effects of immersion virtual reality. Aviation, Space, and Environmental Medicine.

Relander, B. (2014). How to market to Gen Z, the kids who already have \$44 billion to spend. Entrepreneur Media.

Rheingold, H. (1991). Virtual Reality: Exploring the Brave New Technologies. Simon \& Schuster Adult Publishing Group.

Somyürek, S. (2014). Öğretim sürecinde z kuşağının dikkatini çekme: artırılmış gerçeklik. Eğitim Teknolojisi Kuram ve Uygulama, 4(1), 63-80.

Steuer, J. (1992). Defining virtual reality: Dimensions determining telepresence. Journal of communication, 42(4), 73-93.

Subramanian, R. \& Marsic, I. (2001). VIBE: virtual biology experiments. Tenth International World Wide Web Conference, pp 316-325, Hong Kong. 
Tax'en, G. ve Naeve, A. (2002). A system for exploring open issues in VR-based education. Computers \& Graphics, 26, 593-598.

Tilhou, R., Taylor, V., \& Crompton, H. (2020). 3D Virtual Reality in K-12 Education: A Thematic Systematic Review. In Emerging Technologies and Pedagogies in the Curriculum (pp. 169-184). Springer, Singapore.

Üzümcü, E., Akın, B., Nergiz, H., İnözü, M. ve Çelikcan, U. (2018). Anksiyete Bozukluklarında Sanal Gerçeklik. Psikiyatride Guncel Yaklasimlar-Current Approaches in Psychiatry, 10(1), 99-107.

Vesisenaho, M., Juntunen, M., Häkkinen, P., Pöysä-Tarhonen, J., Fagerlund, J., Miakush, I., \& Parviainen, T. (2019). Virtual Reality in Education: Focus on the Role of Emotions and Physiological Reactivity. Journal of Virtual Worlds Research, 12(1).

Webster, R. (2016). Declarative knowledge acquisition in immersive virtual learning environments. Interactive Learning Environments, 24(6), 1319-1333.

Yıldırım, A. ve Şimşek, H. (2006). Sosyal bilimlerde nitel araştırma yöntemleri. Seçkin Yayınc1lı.

Youngblut, C. (1998). Educational Uses of Virtual Reality Technology (No. IDA-D-2128). Institute For Defense Analyses Alexandria VA.

\section{Summary}

\section{Statement of Problem}

Virtual reality (VR) technologies have begun to take their place in our daily lives and they have been used in a wide range of technologies from health to tourism. VR technologies can be defined as a three-dimensional realistic simulation experience produced by the computer (Mann et all., 2018). In general, VR is defined as 3D applications in which individuals can experience real-life experiences in a virtual environment, feel and interact with the developed 3D environments (Carrozzino, \& Bergamasco, 2010; Çavas, Çavas \& Can, 2004; Rheingold, 1991). It is important to examine these technologies, as they starts to take their place in daily life. VR technologies should be studied in an instructional manner in order to determine their possible usage preferences. In this context, it was aimed to determine the views of secondary school students on the use of VR technologies and their preferences of usage.

\section{Method}

In this study, the case study method was utilized. A total of 29 secondary school students (10 boys and 19 girls) were selected for the research. In the selection of the study group, 
purposive sampling method was preferred. Cochran (1977) states that in the purposive sampling, the group is going to be analyzed is easily accessible and ready for research. A pilot study was conducted with the participants during two weeks. In the pilot study, different types of VR contents were presented to the participants. This pilot study was conducted in order to prevent the participants from getting to know the VR technologies and their positive or negative opinions arising from the first use affect the main implementation. After this pilot study, the participants were separated in pairs independently and all the participants were shown the same contents. During the implementation process, a video (approximately 4 minutes) was shown to the learners. In both implementations, study environments have been prepared especially for the participants to sit and use the directional and selection keys integrated with the device that facilitates movement in VR technology. In addition, $360^{\circ}$ swivel chairs are preferred for easy movement. In content display; VR goggles with control keys were used which can be adjusted according to the head structure.

The semi-structured interview form developed by the researcher was used to collect the data. In the first part of the interview form, there are 3 questions to get the participants' opinions about VR technologies before the implementation. In the second part, there are 8 questions that will reveal the effects of using VR technology. The data were analyzed by content analysis method and the opinions were collected under defined code and categories.

\section{Findings}

Findings revealed that, VR technologies were recognized at high level in secondary school but they were not experienced much in terms of usage. It is determined that VR technologies are used especially for entertainment and educational purposes. In addition, VR is used for educational purposes especially in information technologies, science and social sciences. It can be said that tangible learning experiences has a significant impact in the selection of these courses. Also VR technologies might help to develop effective and enjoyable learning experiences.

\section{Discussion and Conclusion}

Nowadays, VR technologies are recognized by secondary school students. In particular, definitions that emphasize technology and the competence of technology reveal that participants are aware of the structure of VR technology. The decrease in the cost of VR 
technologies in recent years may have increased the availability of these technologies and provided users with more information (Jung, Dieck, Lee \& Chung, 2016).

It was seen that the participants wanted to use VR technologies in daily activities for entertainment purposes. Participants' age groups and the desire to use the technology for the basic production purpose may be effective in the formation of this situation. Similarly, Başaran (2010) states that VR technologies are widely used in different sectors such as entertainment and tourism. The participants also stated that VR technologies can be used in the field of education. Kayabaş1 (2005) stated that the use of VR technologies for instructional purposes will have effective results. It can be said that VR technologies, which participants indicate that they can be used in the field of education, can be used frequently in technology-oriented courses such as information technologies. In addition, they emphasize that VR technologies can be effective in science (biology, chemistry and physics) and social sciences (history and geography) courses. In addition, it is among the opinions of the participants that the use of VR technologies can have important results in many fields from mathematics to astronomy.

When the emotions created by VR technologies on the learners were examined, the participants using the current technology felt themselves in the environment presented. In other words, they emphasized that they have moved to a different environment from their environment. In addition, excitement, happiness and interest were the most emphasized emotions of the participants using VR technology. However, it was also observed that there was a sense of fear in the participants who used VR technology for the first time. It can also be said that this feeling of fear disappears with the use of technology.

One of the most emphasized advantages is that VR technologies can create effective and enjoyable learning environments. In addition participants emphasized that VR can easy observation of impossible to observe situations in an effective manner. Similarly, Aktamış and Arıc1 (2013) stated that one of the most positive aspects of VR technologies is that learners can gain real-life experiences safely in virtual environments without being exposed to real-life hazards. In addition, VR technologies can improve the imagination of learners. It is thought that VR technologies may have some limitations as well as advantages. It is possible to classify these negative aspects as health, social and instructional. In this context, VR technologies in the field of health; the potential for addiction and its impact on eye health are among the limitations most frequently stated by users. In addition, it can be said that VR technologies can cause individuals to be socially isolated from society and real life and decrease the number of friends. 
In addition, when the limitations of VR technologies are examined in terms of instructional, it can be shown that continuously used of these technologies may have negative effects on academic achievement, cause time loss and lack of appropriate content for each course. In addition, the current technology is expensive (Aguinas, Henle \& Beaty, 2001) and the possibility of breaking can be shown to be among its limitations (Tax'en \& Naeve, 2002).

Keywords: Virtual reality, VR technologies, instructional technologies, new trends 